\title{
Some parasitic and bacterial causes of liver affections in ruminants
}

\author{
K. M. El-Dakhly ${ }^{1}$, W. H. Hassan ${ }^{2}$, H. S. Lotfy ${ }^{3}$ \\ ${ }^{1}$ Department of Parasitolog,, ${ }^{2}$ Departement of Microbiology, Faculty of Veterinary. Medicine, Beni- \\ Suef University and ${ }^{3}$ Animal Health Research Institute, Beni-Suef, Egypt.
}

In the present study, a total number of 1576 livers of ruminants, including cattle (924), sheep (487) and camels (165) were examined for detection of different pathogenic agents. Among those, a number of 58 cases (3.68\%) were infected with both parasites and bacteria. Out of this number, 3 cases only (0.19\%) were infected with bacterial species (Lactobacillus lactis lactis), 31 cases (1.97 $\%)$ were infected with parasitic stages only and a number of 24 cases $(1.52 \%)$ were co-infected with both bacteria and parasites. Among the bacterial isolates, 11 genera of bacterial species were found in 27 cases. The obtained results revealed that, all infected cases were cattle. The most prevalent isolate was Enterococcus species which present in 7 cases $(25.92 \%)$ among the totally bacterial infected cases, followed by 5 cases showed Staphylococci $(18.52 \%)$, then both genus Escherichia and genus Lactobacillus, each was found in 4 cases $(14.81 \%)$ and finally 7 genera including; Enterobacter, Micrococcus, Citrobacter, Aerococcus, Pseudomonas, Chrysomonas and Streptococcus; each was found in a single case with a percentage of $3.70 \%$. Concerning the parasitic affections, it has been found that Fasciola species was the most prevalent type of helminthes present in the infected livers. Among all infected livers, 40 cases $(2.54 \%)$ were infected with adult Fasciola gigantica (including 33 cattle and 7 sheep), followed by 8 cases of camels $(0.51$ $\%)$ infected with Hydatid cysts, then 4 cases of sheep $(0.25 \%)$ infected with Cysticercus tenuicollis and finally 3 cases of sheep $(0.19 \%)$ infected with both Fasciola gigantica and Cysticercus tenuicollis. The results revealed that, a considerable high number of co-infected animals $\{24$ cases $(41.38 \%)$ among the totally infected animals $\}$ was existed and this reveals that the parasite facilitates the way to the secondary bacterial infection with the end results of hepatic tissue degeneration and necrosis. So, in abattoirs, great attention must be taken for appropriate evaluation of these pathogenic sources.

Affections of the liver in meat-producing animals constitute a major factor that reduce our national income, either directly through condemnation of the affected livers, or indirectly by their effect on the animal growth and so its meat production (Eid et al., 1998).

Liver abscesses may occur as a result of entrance of pyogenic cocci or other wellorganized pus-producing species to the liver through different routes. These microorganisms play a central role in the generalized and fatal diseases. These hepatic abscesses lead to chronic wasting conditions with subsequent erosions and perforation of the wall of posterior vena cava terminating into entrance of bacteria-rich abscess contents into the circulation (Rubarth, 1960). Moreover, bacterial liver infections may ascend the biliary passage either through static secretions consequent upon obstruction or by continuous spread of the infectious inflammatory process from the duodenum and up the ductal tissues.

Different types of bacterial pathogens can be found in carcasses of slaughtered animals in abattoirs including Salmonella species and Staphyllococcus species (El-Bassiouny and Samaha, 1991), so meat could be considered as an important vehicle in transmitting food-borne diseases from animals to man (El-Aboudi et al., 1987) leading to some outbreaks of food poisonings due to consumption of meat contaminated with Salmonella organisms (Mousa and Yassein, 1987).

Parasitic cirrhosis is occasionally seen in domestic animals, and its great significance referred to migration of parasitic larvae such as Ascaris sp. and Fasciola sp. Large number of larvae may result in hepatic necrosis and so cirrhosis takes place (Fischer, 1974). The principal effect of hepatic cirrhosis is the 
interference with blood flow via many hepatic ramifications and this impaired function may be reflected on either body viscera such as congestion of spleen and other organs (Thomas and Ronald, 1983).

Liver flukes belonging to genus Fasciola are an important parasitic cause that leads to liver affections. The most common lesions resulted from both mechanical and toxic irritation of these large parasites. Therefore, jaundice develops in severe infestations with the usual outcome is the condemnation of this affected liver in abattoirs (Ojo, 1993).

The present work aims to detect the possible liver affections in ruminants referred to both parasitic and bacterial origins and highlight to the proper control measures as well as hygienic procedures must be applied in abattoirs to prevent these affections and consequently keep the liver tissue save guard for consumers.

\section{Materials and methods}

Animals. A total number of 1576 livers of cattle, sheep and camels of both sexes and different ages were examined in Beni-Suef abattoir.

Samples. Careful postmortem examination was carried out of livers of slaughtered animals. The liver capsules were grossly examined and several incisions were made throughout the hepatic tissue. Liver specimens showed either parasitological infestations or pathological lesions were collected (Eid et al., 1998).

Media used for isolation . (Collee et al., 1996)

1-Tryptone soya agar: (Biolife).

2-Brain heart infusion broth: (Biolife).

3-Tryptone soya broth: (Oxoid).

4-Blood agar medium:

5- Robertson's Medium (Cooked meat medium):

Biochemical identification of the recovered strains. API $20^{\circledR}$ kits (E BioMerieux 69280 Marcy- l'Etoile/France) were used for Biochemical identification of recovered isolates API 20 Staph for identification of members of Staphylococci API 20 Strept for identification of members of Streptococci API 20 E for identification of members of Enterobacteriaceae

Bacteriological examination. The surface of the affected liver was touched by hot spatula then incision was made by sterile scissor. Samples to be examined were divided into two portions. With a sterile loop the sample was taken from the lesion and inoculated into the enrichment broth, Tryptone Soya Broth "TSB". Another inoculum was cultivated into Robertson's medium for recovery of an aerobic bacteria The inoculated broth was incubated for $24 \mathrm{~h}$ at $37{ }^{\circ} \mathrm{C}$ with the cooked meeat broth in Gas Pack system with gas Pack kits, after which loopful from the TSB culture and form Robertson's medium was inoculated onto two plates Tryptone soya agar (Biolife), one of which incubated aerobically and the other was inoculated anaerobically.

Morphological examination. The recovered colonies were examined microscopically by Gram's method to observe the morphology, arrangement and staining reaction.

Motility. The isolated organisms were stabbed with straight wire into the semisolid agar tubes and incubated at $37^{\circ} \mathrm{C}$ for 24-48 hours (Cruickshank, 1975).

Parasitological investigations. The collected parasites were isolated and identified according to Soulsby (1982). The part of the liver tissue affected by the detected parasites was taken and carefully incised, then the collected tissue specimens were fixed in $10 \%$ neutral buffered formol saline for at least 24 hours and were routinely processed. Paraffin embedded specimens were sectioned at $4-6$ um thickness, for further histopathological examination. These sections were stained with Haematoxyline and Eosin (H \& E) according to Bancroft and Stevens, (1996).

\section{Results}

Bacteriological investigations. Out of 1576 examined livers (924 cattle, 487 sheep and 165 camels), 27 cases were infected with different bacterial isolates and all of them were cattle. Among those, 11 different bacterial genera were recovered from the totally infected animals. These bacterial-infected animals included 3 cases infected with bacterial isolates only (Lactobacillus lactis lactis), while 24 cases showed mixed infections of both parasitic and bacterial origins.

Among the co-infected cases, 7 cases infected with members of genus Enterococcus, 5 cases infected with members of genus Staphylococcus, 4 cases infected with species belonging to genus Escherichia, 4 cases infected with members of genus Lactobacillus, as well as 7 cases each one infected with a separate genus.

The present data pointed out that, the most prevalent isolate in the totally bacterial-infected animals, was belonging to Enterococcus species $(25.92 \%)$, followed by those infected by Staphylococci (18.52\%), then those infected by Escherichia and Lactobacillus (each is $14.81 \%$ ). The remaining genera were present in lower percentage (each of $3.70 \%$ ). 
Table (1): Incidence of bacterial, parasitic and co-infections in livers of the examined animals.

\begin{tabular}{|c|c|c|c|c|c|c|c|c|c|}
\hline \multicolumn{2}{|c|}{$\begin{array}{l}\text { No. of examined } \\
\text { animals }\end{array}$} & \multirow{2}{*}{\multicolumn{2}{|c|}{ Infected animals }} & \multirow{2}{*}{\multicolumn{2}{|c|}{$\begin{array}{c}\text { Animals only } \\
\text { infected with } \\
\text { bacteria }\end{array}$}} & \multirow{2}{*}{\multicolumn{2}{|c|}{$\begin{array}{l}\text { Animals only } \\
\text { infected with } \\
\text { parasites }\end{array}$}} & \multirow{2}{*}{\multicolumn{2}{|c|}{ Mixed infections }} \\
\hline Cattle & 924 & & & & & & & & \\
\hline $\begin{array}{c}\text { Sheep } \\
\text { Camels }\end{array}$ & $\begin{array}{l}487 \\
165\end{array}$ & No. & $\%$ & No. & $\%$ & No. & $\%$ & No. & $\%$ \\
\hline Total & 1576 & 58 & 3.68 & 3 & 0.19 & 31 & 1.97 & 24 & 1.52 \\
\hline
\end{tabular}

Table (2): Incidence of bacterial, parasitic and co-infections among the totally infected livers.

\begin{tabular}{cccccccc}
\hline \multirow{2}{*}{ Total No. of infected animals } & \multicolumn{2}{c}{$\begin{array}{c}\text { Livers infected only with } \\
\text { bacteria }\end{array}$} & \multicolumn{2}{c}{$\begin{array}{c}\text { Livers infected only with } \\
\text { parasitic stages }\end{array}$} & \multicolumn{2}{c}{ Co-infected livers } \\
\cline { 2 - 7 } & No. & $\%$ & No. & \% & No. & $\%$ \\
\hline 58 & 3 & 5.17 & 31 & 53.45 & 24 & 41.38 \\
\hline
\end{tabular}

Table (3): Bacterial isolates recovered from infected livers.

\begin{tabular}{|c|c|c|c|}
\hline Genus & Species & No. of infected cases & $\begin{array}{c}\text { Percentage of infection (among } \\
\text { the bacterial infection) }\end{array}$ \\
\hline \multirow{3}{*}{ Enterococcus } & E. faecalis & & \\
\hline & E. faecium & 7 & 25.92 \\
\hline & E. durans & & \\
\hline Staphylococcus & S. lentus & 5 & 18.52 \\
\hline \multirow{2}{*}{ Escherichia } & E. coli & 3 & \multirow{2}{*}{14.81} \\
\hline & E. fergusonii & 1 & \\
\hline \multirow{2}{*}{ Lactobacillus } & Lc. lactis lactis & 3 & \multirow{2}{*}{14.81} \\
\hline & Lc. Lactis cremoris & 1 & \\
\hline Enterobacter & E. sakazaki & 1 & 3.70 \\
\hline Micrococcus & Micrococcus spp. & 1 & 3.70 \\
\hline Citrobacter & C. freundii & 1 & 3.70 \\
\hline Aerococcus & A. viridans & 1 & 3.70 \\
\hline Pseudomonas & Ps. aeruginosa & 1 & 3.70 \\
\hline Chrysomonas & Ch. Luteola & 1 & 3.70 \\
\hline Streptococcus & Strept. pneumoniae & 1 & 3.70 \\
\hline Total & & 27 & , \\
\hline
\end{tabular}

Table (3) revealed more than species of the same genus e.g. a case of cattle infected with Enterococcus fascium and E. durans, and another case showed species of different genera e.g. certain case revealed Enterococcus durans, E. facium and Lactobacillus lactis lactis.

Parasitological investigations. A total number of 1576 liver of ruminants (924 cattle, 487 sheep and 165 camels) were examined in Beni-Suef slaughter house in Beni-Suef governorate. Among those, 58 liver were infected with both parasitic and bacterial pathogens. A number of 55 cases were parasitic-infected $(3.49 \%)$ and a number of 24 cases $(1.52 \%)$ infected with both parasitic and bacterial pathogens (Table 1).

Among the parasitic-infetced cases, distribution of different parasitic stages occurs as follows: all the parasitic-infected cattle (33) are shown to be infected with adult Fasciola sp. in different degrees of infections; among 14 infected sheep, 7 cases were infected with Fasciola sp. only, 4 cases were infected with Cysticercus tenuicollis and 3 cases were infected with both types. With respect to camels, 8 cases were infected only with Hydatid cyst. (Table 4).

Fasciolosis. Out of 1576 examined ruminants, 43 cases (40 cattle +3 sheep) $(2.73 \%)$ were infected with Fasciola gigantica in their livers.

Most of the infected livers were dark brown in color, hard and tough in consistency. Moreover, the affected bile ducts were thickened, tortous and elevated above the liver surface. On cut section, they revealed presence of inspissated bile mass and may be associated with gritting sound (in severe infected cases).

Microscopically, all Fasciola-infected livers showed the same picture of fasciolosis, but in different degrees according to the stage of the disease. In general, different grades of biliary cirrhosis in the main and the neighboring bile ducts, bile ductules mononuclear leucocytic infiltration in the form of eosinophils, 


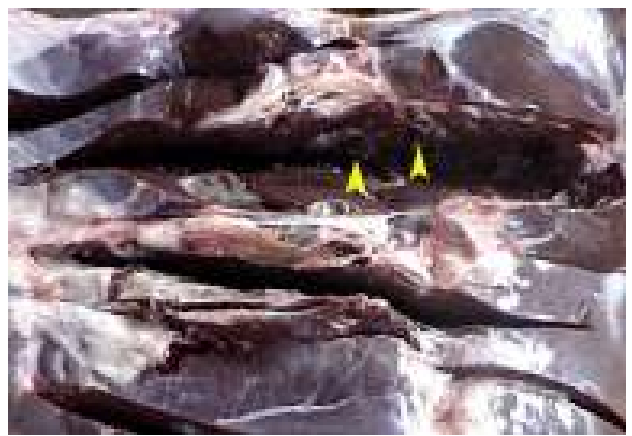

Fig. (1): Cross section with several incisions of bovine liver infetced with Fasciola spp. Arrows point out to the adult fasciolids.

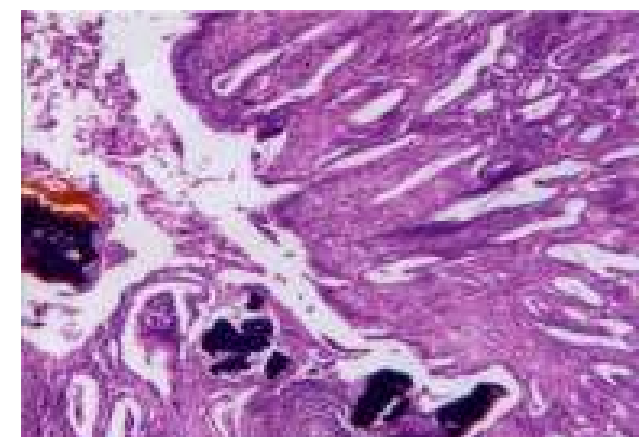

Fig. (2): Bile ducts showed hyperplasia (due to irritation caused by adult fasciolids) of the mucosa associated with deposition of calcium salts and bile pigments,notic the presence of leuckocytic infilteration in the mucosa (H\&E x200)

Table (4): Incidence of liver affections among different animal species.

\begin{tabular}{|c|c|c|c|c|c|c|c|}
\hline \multicolumn{2}{|c|}{ Examined animals } & \multicolumn{2}{|c|}{ Bacterial species only } & \multicolumn{2}{|c|}{$\begin{array}{c}\text { Parasitic } \\
\text { stages only }\end{array}$} & \multicolumn{2}{|c|}{ Co-infection } \\
\hline Species & No. & No. & $\%$ & No. & $\%$ & No. & $\%$ \\
\hline Cattle & 924 & 3 & 0.32 & 9 & 0.97 & 24 & 2.60 \\
\hline Sheep & 487 & - & - & 14 & 2.87 & - & - \\
\hline Camels & 165 & - & - & 8 & 4.85 & - & - \\
\hline Total & 1576 & 3 & 0.19 & 31 & 1.97 & 24 & 1.52 \\
\hline
\end{tabular}

Table (5): Identification of the parasitic stages (adults and larval stages) among the parasiticinfected livers of the infected animals.

\begin{tabular}{|c|c|c|c|c|c|c|c|c|c|}
\hline \multicolumn{2}{|c|}{ Examined animals } & \multicolumn{2}{|c|}{ Fasciola sp. } & \multicolumn{2}{|c|}{$\begin{array}{l}\text { Cysticercus } \\
\text { tenuicollis }\end{array}$} & \multicolumn{2}{|c|}{$\begin{array}{c}\text { Fasciola sp. }+ \\
\text { Cysticercus } \\
\text { tenuicollis }\end{array}$} & \multicolumn{2}{|c|}{ Hydatid cyst } \\
\hline Species & No. & No. & $\%$ & No. & $\%$ & No. & $\%$ & No. & $\%$ \\
\hline Cattle & 924 & 33 & 3.57 & - & - & - & - & - & - \\
\hline Sheep & 487 & 7 & 1.44 & 4 & 0.82 & 3 & & - & - \\
\hline Camels & 165 & - & - & - & - & - & - & 8 & 4.85 \\
\hline Total & 1576 & 40 & 2.54 & 4 & 0.25 & 3 & 0.19 & 8 & 0.51 \\
\hline
\end{tabular}

lymphocytes and plasma cells. The main bile ducts suffered from hyperplasia, of its mucosal epithelium with projections of its mucosal glands. Budding of newly formed bile ductules was also noticed. The portal triads showed fibrosis with mononuclear leucocytic infiltration. Different forms of cholangitis were also persent, usually chronic. Blood vessels of the portal triads suffered from vasculitis. The ductal epithelium of different bile ducts showed calcification with deposition of calcium salts and bile pigments in their lumens. In addition, dilatation of hepatic sinusoids was also noticed.
Cysticercosis. Out of 487 examined sheep livers, only 7 cases were found to be infected with Cysticercus tenuicollis $(0.82 \%)$ attached to their livers by long necks, together with no gross reaction could be detected at the point of attachment to the liver surface.

Microscopically, the infected livers showed minimal degenerative changes in the hepatocytes in the form of vacuolar degeneration and coagulative necrosis.

Hydatidosis. Out of 165 examined camel livers, only 8 cases $(4.85 \%)$ were found to be infected with the larval stage Echinococcus granulosus, 
the Hydatid cyst. These cysts were few in number, small in size and spcherical in shape. The general architeture of the infected livers was somewhat upnormal with pale brown color and loose hepatic parenchyma. Microscopically, leucocytic infiltration of eosinophils and lymphocytes was seen together with fibrous connective tissue.

\section{Discussion}

Due to being liver is an important meat byproduct, it must be kept, as possible, free from all pathogens including bacteria and parasites that greatly affect the liver tissue rendering it unfit for human consumption through partial or total condemnation in abattoirs.

In the present study, high percentage of parasitic affections $(31 / 58 \quad\{53.45 \%\})$ was revealed among the totally infected livers. The different parasitic stages were Fasciola gigantica, Cysticercus tenuicollis and Hydatid cyst. Adult Fasciola spp. was the predominant parasitic species that found in different degrees of infection inducing variable lesions in both parenchyma and bile ducts. High incidence of fasciolosis among the totally parasitic infected animals may be referred to the grazing behaviour of animals (El-Dakhly, 2004 and Gebely, 2004) together with the presence of its intermediate hosts, Lymnaea snails, all allow the induction of the disease. Identification of the disease depend upon the presence of adult worms in different locations in the hepatic tissue either in parenchyma or in the bile ducts, as well as on the histopathological lesions supported with detection of different forms of cirrhosis in hepatic tissue. This view was reported by Mahmoud et al., (1989) and Fahmy and El-Attar (1990).

The gross appearance of all infected livers obtained from the examined animals varied according to the degree of infection (Farrah, 1993). Microscopically, several cases showed hyperplasia of the main bile ducts revealing chronic cholangitis together with excessive proliferation of mucosal glands and degenerative changes with necrosis of the epithelium. These lesions were due to the presence of mature fasciolid worms within the lumen of the intrahepatic bile ducts that induce a persistent irritation (due to the secreted toxins) leading to hyperplastic proliferations that were emphasized by papillomatous projections and the formation of newly formed bile ducts (El-Mahdy, 1975).

Moreover, catarrhal cholangitis associated with lymphocytic infiltration is present in several cases, also, eosinophilic infiltration was seen due to migration of parasitic larvae, and this picture might be attributed to the toxic secretions of the parasites. Also, several cases of vacuolar degenerations appeared and may be attributed to the metaplastic changes occurred in the ductal epithelium as a result of continous irritation against the parasite. Similar findings were obtained by Eid et al., (1998). It is important to point out that parasitic remnants provide a nidus for bacterial proliferation and the parasites may physically introduce bacteria into the biliary tree during their migration (Herschel and Carpenter, 1998) from the duodenum. Therefore, bacterial cholangitis has an important and frequently dominant role in the pathogenesis and clinical course of biliary disease due to these parasitic infections.

It would likely indicated that, cholangitis and cholecystitis induced by adult liver flukes are sufficient to cause mechanical obstruction of biliary system (Chen and Mott, 1990).

The present investigation revealed 11 genera of isolated bacteria. Table (3) showed that bacterial isolates belonging to Enterococci, Staphylococci, and Escherichia were in the higher percentages 25.92, 18.52 and $14.81 \%$ respectively. These results agree with those obtained by Salem (1989) who revealed Staphylococcus aureus was isolated at a rate of $20 \%$. On the other hand, Hegazy (1990) revealed a high percentage of Escherichia coli in the examined meat $(80 \%)$ and he referred this high infection rate to the improper sanitary conditions in the slaughter houses.

In our opinion, the closed relationship between bacterial and parasitic infections was well distinct. Although bile is being sterile, due to constant bile flow and the bacteriostatic properties of the bile (Herschel and Carpenter, 1998), the obstruction of biliary system and its stagnation might occur as a result of parasitic infections, then bacteria gain access to the biliary system through either papilla or portal circulation. Although the duodenum and jujenum normally conatin only scant-gram positive bacteria, when bile flow is interrupted, the small intestine is colonized by colonic type organisms. Partial obstruction of biliary system is associated with a higher rate of infection than a complete one, and the bacterial infection is more likely in the presence of gallstones.

The presence of granulomas produced by adult trematodes, their eggs or even their remnants in the liver portal triads act as foci for colonization of Staphylococcus species, which in 
the presence of staphylococcal bactermia might be implicated in the formation of pyogenic liver abscesses (Teixeira et al., 1996; Teixeira et al., 2001).

Due to being that Gram-positive bacteria actively bind to matrix-protein-coated surfaces, Staphylococcus species might adhere to laminin, fibronectin and type IV cpllagen which are compounds of extracellular matrix of granulomas produced by trematodes (Andrade, 1991) and consequently liver abscesses may be formed. Furthermore, formation and degradation of extracellular matrix of chronic granulomas may be also implicated in the pathogenesis of abscesses (Andrade and Grimaud, 1988).

It would be though that, medicinal treatments of animals using some instruments before slaughtering might be an important factor for secondary bacterial infection, by introducing some bacterial species through un-sterilized instruments. In our study, Pseudomonas, species was present in low percentage $(3.70 \%)$ and we think that this bacterial species may be introduced by this way. Our findings revealed that, several cases of infected livers showed polymicrobial infections, and this feature might explain that route of infection might include more than one way.

Moreover, clinical diagnosis of fasciolosis is sometimes difficult, as the most clinical signs in the chronic phase may be indistinguishable from cholangitis referred to origins other than parasites such as bacterial infections (Dobrucali et al., 2004).

Consulting the obtained results, there is no doubt that, the isolated organisms seriously affect the keeping quality of liver as an important meat by-products and so hazards the health of consumers as well. Therefore, improved sanitary conditions in our slaughter houses, hygienic disposal of the condemned parts as well as treatment of parasitic affections in animals preslaughtering must be kept in our mind to produce meat and meat by-products of good quality and save guard the consumers. Furthermore, control of parasitic diseases through eradication of stray dogs and killing of snail intermediate hosts are important tools to reduce the parasitic affections that predispose to several bacterial infections.

\section{References}

Andrade, Z. A. (1991): Extracellular matrix and schistosomiasis. Mem. Inst. Oswaldo Cruz, 86: $61-73$. Andrade, Z. A. and Grimaud, J. A. (1988): Morphology of chronic collagen reabsorption. A study on the late stages of schistosomal granuloma involution. Am. J. Pathol., 132: $389-399$.

Bancroft, J. D. and Stevens, A. (1996): Theory and practice of histological techniques. Chrchill Liveingstone, New York.

Chen, M.G. and Mott, K. E. (1990): Progress in assessment of morbidity due to Fasciola hepatica infection in a review of recent literature. Trop. Dis. Bull. 87:R1 - R38.

Collee, J.G.; Fraser, A.G.; Marmion, B.P and Simmons, A. (1996): Mackie \& Mc Cartney Practical medical microbiology. $14^{\text {th }}$ ed. The English language book society and churchill livingstone. Ediunburgh and New York.

Cruickshank, R.; Duguid, J.P.; Marmion, B.P. and Swain, R.H.A. (1975): Textbook of medical microbiology. $11^{\text {th }}$ ed. The English language book society and churchill living stone. Edinburgh and NewYork.

Dobrucali, A.; Yigitbasi, R.; Erzin, Y.; Sunamak, O.; Polat, E. and Yakar, H. (2004): Fasciola hepatica infestation as a very rare cause of extrahepatic cholestasis.World J. Gastroenterol. 10: 3076 - 3077 .

Eid, R. A.; El-Mahdy, M. M.; Hamouda, M. A. and Fatma, M. Darwish (1998): Some studies on parasitic liver affections of camels in Egypt. Assiut Vet. Med. J., 38 (76): $121-137$.

El-Aboudi, A.; Nased, R. and Ahmed, N. (1987): Hygienic quality of beef carcasses produced at Mousl abattoir. Vet. Med. J., 35: $73-82$.

El-Bassiouny, A. and Samaha, H. (1991): Role of abattoir effluents in contaminating carcasses with some food poisoning bacteria. Assiut Vet. Med. J., 25 (49): 108 - 112.

El-Dakhly, Kh. M. (2004): Evaluation of excretory/ secretory antigen for protection against sheep fasciolosis. Ph. D. Thesis, Fac. Vet. Med. Cairo Univ. Beni-Suef, Egypt.

El-Mahdy, M. M. (1975): Histopathological studies of necrotic foci in the liver of sheep. M.V.Sc Thesis, Fac. Vet. Med. Cairo University.

Fahmy, M. F. and El-Attar, S. R. (1990): Pathological study on fascioliasis in camel and solipeds. Egypt J. Comp. Pathol. Clin. Pathol., 3 (2): 285 - 291.

Farrah, M. A. (1993): Pathological studies on Cysticercus tenuicollis and Fasciola gigantica in farm animals in Sharkia governorate. M. V. Sc. Fac. Vet. Med. Zagazig Univ. Egypt.

Fischer, J. E. (1974): Hepatic coma in cirrhosis, portal hypertension and following portcaval shunt: its etiological and the current status of its treatment. Arch. Surg., 108: 325 -336 .

Gebely, M. A. (2004): Prevalence of some parasitic diseases in small ruminants in Siwa Oasis. M. V. Sc. Thesis, Fac. Vet. Med. Beni-Suef, Egypt.

Hegazy, S. (1990): The role of meat and its products in transmitting microorganisms causing food poisoning in man. M. V. Sc. Thesis, Fac. Vet. Med. Alex Univ, Egypt.

Herschel, A. and Carpenter, M. D. (1998): Bacterial and parasitic cholangitis. Mayo Clin. Proc., 73: 473 - 478.

Mahmoud, A.Z.; Youssef, M. S. and Ibrahim, M.K. (1989): Morphopathological studies on some liver affections in camel. Egypt J. Comp. Pathol. Clin. Pathol., 2 (1): $94-$ 103.

Mousa, M. and Yassein, M. (1987): Enterobacteriacae of slaughtered carcasses of sheep and goats with special reference to Salmonellae. Alex. Vet. Med. Sci., 3 (1): 57 64.

Ojo, S. A. (1993): A survey of pathological conditions in slaughtered goats at Zaria slaughter houses. 
Rubarth, S. (1960): Hepatic and subphrenic abscesses in cattle with rupture into vena cava caudalis. Acta Vet. Scand. , 1: $363-382$.

Salem, M. (1989): Microfilaria of pastena. M. V. Sc. Thesis, Fac. Vet. Med. Beni-Suef., Egypt.

Soulsby, E. J. (1982): Helminthes, Arthropoda and Protozoa of domesticated animals. $7^{\text {th }}$ ed. Bailliere Tindal \& Casell Ltd. London.

Teixeira, R.; Ferreira, M. D.; Brasileiro Filho G. and

Lumbertucci, R. (1996): Pyogenic liver abscesses and acute Schistosomiasis mansoni: report on 3 cases and experimental study. Trans. R. Soc. Trop. Med. Hyg., 90: 280 $-283$.

Teixeira, R.; Francis, J. P.; Giovanna, P. C.; Vandack, N.; Paulo, M. Z. and Lambertucci, R. (2001): Schistosomiasis mansoni is associated with pyogenic liver abscesses in the state of Minas Gerias, Brazil. Mem. Inst. Oswaldo Cruz, 96: 143 - 146.

Thomas, C. J. and Ronald, D. H. (1983): Veterinary Pathology. $8^{\text {th }}$ ed. Bailliere Tindall, London, Great Britain.

$$
\text { بعض الأسباب الطقيلية والبكتيرية لأصابات الكبد في المجترات }
$$

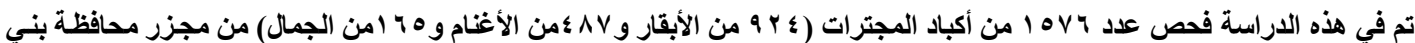

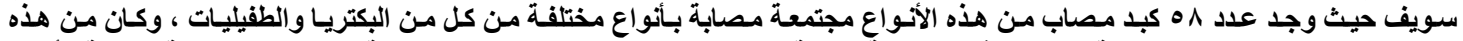

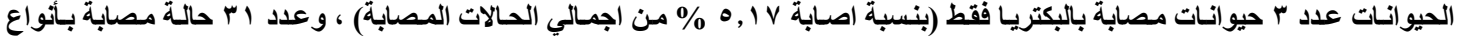

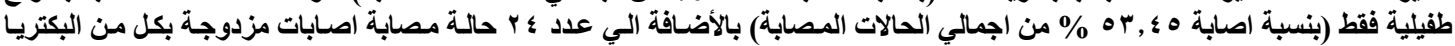

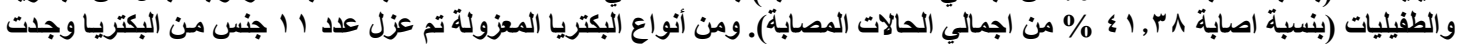

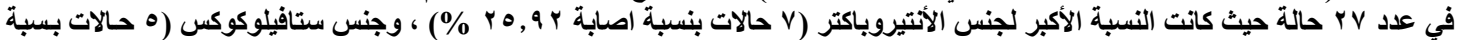

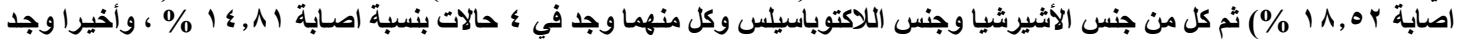

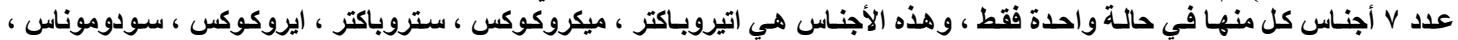

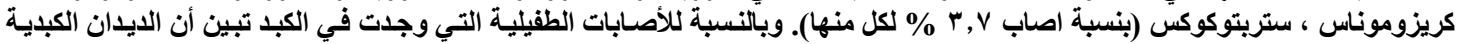

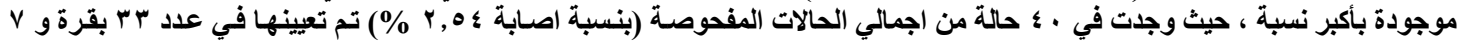

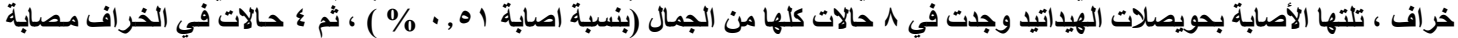

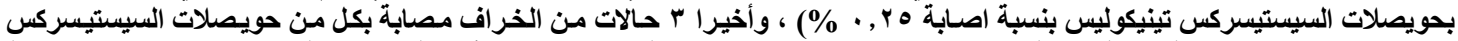

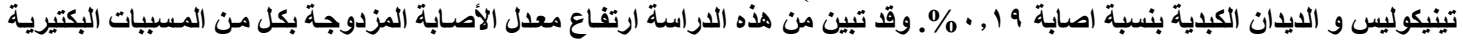

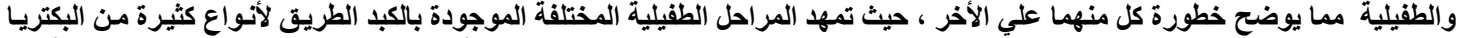

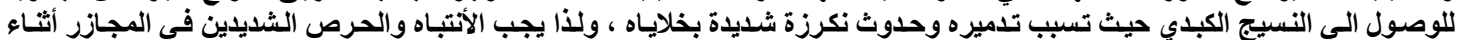

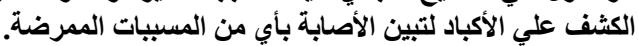


